DOI: $10.20472 / T E .2015 .3 .1 .007$

\title{
CONCLUSIONS FROM THE EU-RELATED TRAINING NEED ASSESSMENTS IN ESTONIA IN 2002-2013
}

\author{
VILJAR VEEBEL, LIINA KULU, RAUL MARKUS
}

\begin{abstract}
:
The aim of the study is to assess whether the training need assessment instruments used in Estonian public sector have been appropriate in identifying the gap between actual and desired competencies. The analysis is based on the comparison of training needs assessment techniques applied in studies conducted in Estonia in 2002, 2008 and 2013 to determine the EU-related training needs of the local officialdom. Particular attention is devoted to the scope of needs' identification process, the occurrence of answer 'as expected' on 'dangerous' questions, and the subjective nature of self-assessment known as the Dunning-Kruger effect.

Findings: Training need assessment in public administration has been conducted in a non-systematic manner in Estonia not only with regard to the specific problems occurred at centrally co-ordinated level, organizational level and with regard to the training of top-ranked officials, but also related to the lack of consistent approach to the techniques used. To get an adequate overview, self-assessment should be combined with other instruments offering measurable information.
\end{abstract}

\section{Keywords:}

training needs assessment, public sector, self-assessment, Dunning-Kruger effect, human resource management

JEL Classification: H10, 120

\section{Authors:}

VILJAR VEEBEL, Tartu University and Estonian National Defence College, Estonia, Email: LIINA KULU, Bank of Estonia, Estonia, Email:

RAUL MARKUS, Tallinn University of Technology , Estonia, Email:

\section{Citation:}

VILJAR VEEBEL, LIINA KULU, RAUL MARKUS (2015). Conclusions from the EU-related training need assessments in Estonia in 2002-2013. International Journal of Teaching and Education, Vol. III(1), pp. 88-103., 10.20472/TE.2015.3.1.007 


\section{Introduction}

In an organisation, training as an integral part of the Human Resource Management (HRM) contributes to the organisation's competitiveness and organisational performance through improving employees' competencies and job performance. At the country level, the competency of individuals administrating the system determines the administrative capacity of the public sector. Thus, training and development practices in public sector will be at least as important as improving the employees' performance in private sector, since in general terms they contribute to the country's capacity to represent its interests domestically as well as internationally. The widened scope of public administration over the past 40-50 years as well as challenges posed by globalisation, interdependence, multiculturalism, and rapidly evolving IT-technologies have posed new challenges also to the public administration training. According to Waxin and Bateman (2009), public organisations mainly face difficulties related to training needs assessment (TNA), training transfer (i.e. the actual performance of new skills) and training effectiveness evaluation.

The TNA in public administration should, in principle follow the same logic applied to the training needs assessment in general. The gap between the current and the expected situation should be systematically identified; only instead of the expectations of the organisation, the expectations of the state on the competencies of the civil servants should be defined. The discrepancies in outcomes should be determined and placed in order of priority, accompanied with the identification of the motivation of civil servants to participate in training programs. Based on academic literature, alongside the "classical" human resource management techniques (i.e. survey questionnaire compiled by the employee itself and the employee's evaluation form compiled by the employee's superior, supplemented by an interview with employee's superior or a training manager) a variety of other instrument (such as tests, consultations, direct observations, process maps, performance evaluation, etc.) could be used and combined to identify training needs (see e.g. Moore and Dutton, 1978; Gupta, 1999; McGehee and Thayer, 1978; a comprehensive generalized analysis of the purposes and methods of the needs assessment including the selection of needs assessment variables across twelve disciplines is provided by Moseley and Heaney (1994)). The choice of techniques and instruments depends on the profile, size, structure and objectives of the particular organisation, corporate climate, legal basis, funding, etc (see also Cekada, 2010; Hannum and Hansen, 1989 in Cekada, 2010). Particularly in public administration, it should be emphasized that the development activities are largely influenced by the governmental structure, the status of staff, the conditions for the entry to the civil service and the level of education required for the position (see Bossaert et al., 2001) as well as in most countries the objectives of the training for public service personnel are usually defined in the civil service legislation, either in the civil service act or in specific regulation on training (see OECD, 1997). Thus, public sector organizations are not as much 
autonomous in their decisions in respect of training as private sector organizations are (see, Moore and Dutton, 1978; Coetzee, 2004). Therefore, considering the specifics of the public sector (i.e. the objectives of the training for public service personnel usually defined in the civil service legislation; the training needs' identification process as well as training activities in public sector mostly centrally co-ordinated rather than based on a specific needs of the particular organization; usually large organizations with a multi-level hierarchical structure; possible inconsistency in reforms, etc.), the risks of the nonidentification of the actual training needs are definitely higher than in private sector organizations. Also, according to Patton and Pratt (2002), state agencies conduct substantially less formal assessment of employee training needs than the private sector (Patton and Pratt, 2002, in Waxin and Bateman, 2009).

The aim of the current study is to assess whether the human resource management instruments used in Estonian public sector have been appropriate in identifying the gap between the actual knowledge and desirable competencies and assuring that training has been focused in the right areas. To approach the training needs assessment in a systematic way, authors compare the TNA techniques applied in the studies conducted in Estonia respectively in 2002, 2008 and 2013 to determine the EU-related training needs of the local officialdom. The concentration on one particular area helps to observe the results of the surveys in a comparative and dynamic perspective, allowing the comparison of the results obtained using different techniques. Particular attention will be devoted to the scope of the needs' identification process, the occurrence of the answer 'as expected' on the 'dangerous' questions, and the subjective nature of self-assessment known as the Dunning-Kruger effect.

The concentration on the assessment of EU-related training needs has also extremely practical value. More precisely, increasing the knowledge and skills of local EU-related civil servants is important in all EU member states, as these are primarily the very category of officials who ensure a country's representation and policy impact at the EUlevel. The need for well-targeted EU-related training has even wider resonance both in the small member states and in countries with less experience in administrative capacity building (e.g. transition countries from the Central and Eastern Europe) in comparison to the advanced EU member states, as the increase in administrative as well as EU-related competencies in these countries contributes to their empowerment both in the EU decision-making process and in international relations in general. Particularly for some member states from Central and Eastern Europe (including Estonia), a significant challenge to the administrative capacity of the local EU-officialdom is posed by the forthcoming EU-Presidencies. A successful EU presidency requires local officials to have a good knowledge of the EU-related issues as well as excellent interpersonal, decisionmaking, negotiating, cooperation and communication skills. Since the above-mentioned skills could not be developed overnight, continuous administrative capacity building 
towards the European Union especially in the EU member states from Central and Eastern Europe is needed, based on the well-targeted identification of specific needs of the target groups. In this context, Estonian experience in assessing the EU-related training needs of local officialdom could have wider resonance.

\section{Theoretical dilemmas related to the selection of the TNA techniques}

Theoretically, the main dilemma related to the selection of TNA techniques concerns the subjective nature of the self-assessment included in the training needs gap analysis and the discrepancies related to the uncertainty in the future.

More precisely, following Miller and Osinski (2002), the gap between the current and the necessary individual and organizational performances includes differences between: a) what the organization expects to happen and what actually happens, b) current and desired job performance, c) existing and desired competencies and skills. For example, as traditionally a training needs assessment asks employees to rank desired training courses, employees often identify their training wants versus their training needs (Cekada, 2011). Another form of the subjective nature of the self-assessment is described in academic literature as the Dunning-Kruger effect (Kruger and Dunning, 1999; Dunning et al., 2003), a socio-psychological phenomenon of self-assessment of competencies, skills and knowledge being inadequate. As stipulated by Dunning et al. (2003), '.../ in many social and intellectual domains, people are unaware of their incompetence. Where they lack skill or knowledge, they greatly overestimate their expertise. /.../ The skills needed to produce correct responses are virtually identical to those needed to evaluate the accuracy of one's responses. Thus, if people lack the skills to produce correct answers, they are also cursed with an inability to know when their answers or anyone else's, are right or wrong. They cannot recognize their responses as mistaken, or other people's responses as superior to their own'. Based on the academic literature, the Dunning-Kruger effect occurs in the form of over- as well as underestimation of competencies and skills. The overestimation of skills described previously is supported e.g. by Pazicni and Bauer (2014), stipulating that mistakenly high self-ratings (i.e. 'illusions of competence') are typically explained by a metacognitive deficiency of the unskilled or less-experienced individuals. At the same time, inaccurate self-assessment could be observed also in case of highly skilled individuals - according to Kruger and Dunning (1999), highly skilled individuals consistently underestimate their performance relative to their peers, as they mistakenly assume that everybody' $s$ performance is at the same level as their performance and their own performance is unexceptional. Also specific aspects of inadequate self-assessment have been highlighted in academic literature, e.g. Pallier (2003) described that males were more confident about their performance on a general knowledge test than were females. Based on study conducted among medical students, Lind et al. (2002) concluded that female 
medical students underestimated their performance on a surgical task compared to faculty assessments, while male self-assessments did not differ from faculty assessments. Thus, also other issues (including gender-specific aspect) might influence the over- or underestimation of the knowledge and skills when identifying the training needs.

Another principle issue is related to the question, whether the TNA techniques used enable to identify and map both the priority areas as well as topics where no training is needed. More precisely, in generalised terms TNA seeks to answer the question of whether the organization's needs, objectives, and problems could be addressed by conducting training (see Arthur et al., 2003; Barbazette, 2006). For example, training is not a solution to problems caused by poor system design, inadequate resources or understaffing (see Sorenson, 2002) or poor motivation, morale or learning disabilities (Cekada, 2011). In some cases, increasing employees' skills and knowledge may not resolve the problem or deficiency, and those who conduct assessment must have clear understanding of the problem and must consider all solutions, not just training (Cekada, 2010).

Thus, relying only on a single method may describe an inaccurate picture of the actual training needs. Various levels, methods and approaches definitely contribute to the collection of comprehensive information concerning the actual and necessary levels of skills among individuals under review in as many and varied ways as possible. For example, survey questionnaire, which could include both qualitative and quantitative questions, has several advantages, such as cost-effectiveness, easily administrable to a large population, non-intrusive in comparison to individual interviews, focus groups, etc. At the same time, designing the questionnaire is a critical factor in determining and obtaining unbiased feedback, as each person involved in generating and analysing the data will value the information differently and apply weight to factors which are more meaningful according to their view (McClelland, 1994). Interviews or focus group discussions (involving respectively an interviewer and a single interviewee or a group of people interviewed) allow to obtain more information compared to the survey questionnaires and to have greater understanding of the training needs because of the open-ended conversation, but using interviews and focus group discussions could be time-intensive as well as results might contain several inadequacies e.g. by data bias due to self-reporting, uncategorized answers, partial picture, some people may dominate or be shy in the group, etc. (McCawley, 2009). Thus, to avoid biased feedback a combination of traditional techniques with external evaluation instruments (such as performance evaluation and performance discrepancy mapping, direct observation, testing, etc.) should be used as well as external evaluators should be included. 


\section{Main characteristics of the Estonian public administration system and surveys conducted to identify the EU-related training needs in Estonia in 2002-2013}

After regaining independence in 1991, Estonia - similarly to other EU-member states from Central and Eastern Europe - had to adapt to the enormous changes in a relatively short time during the transition period and to set up a training system for public administration in the 1990s. The legal framework of re-establishing the public administration system in Estonia was settled by the Public Service Act in 1995, defining the staff employed by central government institutions (ministries, administrative agencies, boards and inspectorates, constitutional institutions, county governments) and local governments (226 towns and rural municipalities) as public servants. However, reforms in public sector in Estonia started already earlier. In principle, after restoring the independence in 1991, public sector reforms in Estonia could be divided into three stages (Sarapuu, 2012; Tõnnisson and Randma-Liiv, 2008 in COCOPS Work Package 3; Country Report):

(1) The early transformation phase until 1996, when broad-based structural and administrative reforms were carried out and proper legislative and institutional framework was created (e.g. border guard, central bank, etc.).

(2) The EU-Accession period 1996-2004, when also several administrative reforms were suggested with the focus on the accessibility and quality of public services (e.g. introducing standards for public services, etc.) as well as to the productivity of functions, but as stipulated by Drechsler (2004) only little coordinated results occurred due to the lack of central steering which, according to Tõnnisson and Randma-Liiv (2008), have led to heterogeneity of solutions in individual organizations.

(3) Post EU-Accession period from 2004, when different reforms have been delegated to individual ministries and the Government Office, leading to inconsistency in the public administration reform strategies and to the constant changes in the public management (Tõnnisson and Randma-Liiv, 2008).

At the end of 2012, 138,000 public servants were employed in public administration in Estonia (Includes staff employed by central government institutions, local governments, social security funds and other public sector), $40 \%$ of them were employed by central government institutions and $44 \%$ by local governments. Almost half of the public servants employed by central government (46\%) were under the age of 40 years and almost one third (29\%) were over the age of 50 years. $54 \%$ of state officials were women and $46 \%$ men. Following the distribution of state officials according to length of public service as of the end of 2012, although in general about $52 \%$ of the state officials have worked in public sector more than 10 years, approximately $43 \%$ of the staff working as state officials is working in his/her current institution less than five years. Civil servants' total turnover in 2012 was $11 \%$, being relatively stable during the period 2009-2012 (Avaliku teenistuse..., 2013). 
Public administration in Estonia could be characterised by relatively young officialdom in comparison to that of other OECD countries, as well as state officials working in their current institutions over a relatively short period of time. As the public administration system was basically built at the beginning of the 1990s and central co-ordination of the system was lacking until mid-2000s, the local officialdom is also characterized by relatively limited experience of international co-operation as well as by inconsistency in the public administration reform strategies and centrally coordinated activities.

Inconsistency in reforms and lack of the 'big picture' could also be observed with the regard to the management of the human resources in the public sector. In Estonia, until the entry into force of the Arrangement of the Public Servants' Training in April 2013, the training of state officials was mainly regulated by the internal arrangements within the organization. From April 2013, according to the new regulation every ministry is responsible for recruitment, evaluation and development of the officials in institutions within their areas of responsibility, guided by the legal framework and centrally set advisory guidelines (i.e. strategy documents as well as development plans in particular sector/organization) (see Public Service. www.eesti.ee). The responsibility for developing the civil servants' training system has been divided between two separate institutions the Ministry of Finance and the State Chancellery. Whereas until the end of 2009, only the State Chancellery was centrally co-ordinating the public administration training, from 2010 Ministry of Finance was made responsible for developing the training system in public sector. At the same time, to avoid the politicisation of the high-ranked officials (Secretary-General, Deputy Secretaries General, Director-General, etc.), the State Chancellery still remained responsible for developing the high-ranked officials as well as centrally coordinating the EU-related training needs surveys which have lately resulted in several centrally arranged training courses.

According to the statements expressed, one of the shortcomings of the public administration training system was related to the accreditation of the officials. The Public Service Act, entered into force in 1996, specified that every three year accreditation of the civil servants should take place to assess his/her suitability for the particular position. Although the requirement of accreditation has been valid until 2013, it was considered to be extremely rigorous and formal control mechanism, rather than a useful tool for developing the state officials (Randma-Liiv, 2009; Taavits, 2012; Avaliku teenistuse..., 2013 , etc.). In practical terms the requirement was not systematically followed, and as stipulated by Randma-Liiv (2009), the evasion of the accreditation requirement was even partially considered as normal (or even as a good practice). In 1998, new and more flexible requirement was added to the Public Service Act, specifying that in addition to the accreditation in every three years, also annually development- and assessment discussions should take place which should be more focused on the evaluation of the employee's achievements, future plans as well as training needs. To sum up, in general the regular assessment of the training needs of the state officials in Estonia has been patchy in certain periods. 
Another critical issue related to the public administration training in Estonia is related to the limited resources. More precisely, due to the limited financial resources also the provision of the EU-related training courses in Estonian public sector is limited. According to PRAXIS (2013), although in recent years several centrally planned training programs have taken place, the relatively low level of training has allowed only a small group (approximately 5-6\%) of officials to participate in the training courses. Thus, besides the question whether training is well-targeted or not, the question remains to what extent the civil servants have access to training at all.

Participating in the European Union decision-making is a challenge and an every-day work for a respectful number of state officials and diplomats in all the EU member states. In 2008, in Estonia approximately 500 persons were directly involved in the EU decisionmaking process; all of them either being responsible for preparing the positions, making statements, negotiating and later amending the national legislation. Based on the national strategy for the Estonian Presidency (Eesti Euroopa..., 2014) in 2018, the related personnel managing the activities covers about 1300 persons (including 1000 persons who address issues of content). Additional recruitment of staff foreseen for Estonian Presidency as well as educating the present officialdom about EU affairs and training their skills for being better prepared for their job should be a constant work and a state priority.

To sum it up, characterised by a relatively young officialdom with regard to age, limited earlier experience of international co-operation, high degree of decentralization in the area of personnel development planning in the public sector as well as relatively limited access to the EU-related centrally co-ordinated training programs, public sector in Estonia is relatively vulnerable to risks related to the management of human resources. The comprehensive identification of the EU-related training needs would definitely contribute to the reduction of the risks.

During the period 2002-2013 three separate surveys were conducted to evaluate the level of knowledge of the EU-related local officials and define their specific needs. The first survey was conducted by the private company ESKO Training and Consultancy in 2002, the second survey by an academic institution, University of Tartu EuroCollege in 2008 and the third survey by the local think tank PRAXIS Centre for Policy Studies in 2013. On the basis of the surveys conducted in 2002 and 2008, the EU-related officials' training strategies respectively for the periods 2003-2005 and 2008-2012 were formulated. The survey conducted in 2014 creates the framework of the training strategy for the new period of five years, 2013-2017. All three surveys were ordered by the State Chancellery.

From the methodological point of view, in the first survey conducted in 2002 respondents were asked about what they thought how necessary the knowledge in particular area in their daily work is $(\mathrm{N})$ and how they assess their own knowledge in the respective area (K). Thus, the respondents' opinions of the 'importance of the topics' and 'their knowledge about the topic' were compared and based on the logic that training is needed in the 
areas where topic is of particular importance in the daily work but the actual knowledge is low, the training needs were identified based on the formula $(\mathrm{N})-(\mathrm{K})$. Three topics general knowledge, specific issues and language - were covered in the survey, and the necessity of the topic in the daily work as well as the current knowledge in the respective area were assessed based on the following scale: 5- 'irreplaceable', 4 - 'important', 3 'quite important', 2 - 'not so important', and 1 - 'not important at all'.

The study conducted in 2008 compared the respondent's self-assessments on his/her knowledge and the need for training with his/her assessment of the knowledge and training needs of the respondent's colleagues. Similar method is widely used in surveys where sensitive data (e.g. income level, voluntary contributions, preferences, or even vices) will be asked. Such indirect projections allow receiving more information on the respondent itself as it would be in the case of the direct questions, where respondent is forced to answer on questions that concern himself/herself. Responses were mainly based on a polarized scale ('satisfied', 'rather satisfied', 'rather not satisfied', 'not satisfied' or 'positive', 'rather positive', 'rather negative' and 'negative'), but also openended questions and ten-point scales were used. Questionnaire was combined with 30question EU-related voluntary quiz to compare whether those who assessed their knowledge as excellent/very good actually gain higher results in the test than those who mark their knowledge as medium/weak. In addition to the questionnaire and test, semistructured group interviews were conducted in groups including 1-4 persons to be interviewed.

In the third survey conducted in 2013 again the respondents were asked to self-assess their own EU-knowledge and competencies in particular areas. The assessment of knowledge was based on the scale from 2 to 5 (2 - 'scarce', 3 - 'satisfactory', 4 - 'good', 5 - 'very good') and of the competencies on the scale 'of key importance' ('important', 'less important' or 'very good', 'good', 'satisfactory'). Additionally, the assessment of the general level of the competencies in different categories of the respondents (e.g. minister presiding the council, COREPER representative, person responsible for a particular topic, person presiding a working group or a committee, expert) was asked. The questionnaire was combined with a 360-degree feedback in the form of the questionnaire and focus group interview/discussion.

In principle, the strategy of using techniques based on self-assessment or the assessment of colleagues is also used in other similar studies. In 2006, the Centre of Consultancy Training Geomedia analysed the long-term training needs of the local municipalities, conducting an internet-based survey questionnaire with closed answers where local government officials have self-assessed their own competencies and suggested the training needs, and semi-structured open-answers interviews (Sepp and Noorkõiv, 2006). In 2011, PRAXIS conducted a study on the public administration training system and the training needs assessment. No particular TNA techniques were applied; based on the qualitative analysis a general conclusion has been drawn that the TNA has been conducted in a non-systematic manner at the centrally co-ordinated level, 
organizational level as well as with regard to the training of top-ranked officials (RandaaLiiv 2011). To conclude, the TNA in Estonian public sector has in general based on the self-assessment, combined with the assessment of direct superior, subordinates and to the limited extent the assessment of the colleagues. The potential occurrence of Dunning-Kruger effect has been tested only in the study conducted by the University of Tartu EuroCollege in 2008 (in the form of the 30-question EU-related voluntary test).

\section{Discussion: Have the EU-related training needs' studies conducted in Estonia been appropriate in identifying the training needs gap?}

With regard to the EU-related training needs' studies conducted in Estonia during the period 2002-2013, the authors of the current article would like to point out three issues. Firstly, the training needs' identification should be focused on assessing the current knowledge and the training needs in particular areas, not on the importance of the topics on a broad basis, etc. For example, the survey conducted in 2002 identified the training need as a gap between the importance of the particular topic in the daily work and the assessed level of knowledge in particular area. At the same time, in PRAXIS survey conducted in 2013, respondents have assessed their knowledge on the EU-related issues, including the institutions and decision making process of the $E U$, at the average level or even higher than average, but at the same time still suggested that training is mostly needed on the EU institutions and decision making process. Thus, if the methodology of the study from 2002 have been used also in 2013, probably it would be difficult to capture the training need for the issues related to the institutions and the decision making process of the EU, as the respondents were not directly asked about the training needs and they have only assessed that their knowledge in this area is at the average level or even higher than average. In this context, it is also important that the persons responsible for drawing up the survey and the respondents of the survey have similar understanding of the terminology. For example, having broadly defined closedended questions might be confusing or irrelevant from respondent's perspective (e.g. 'training on EU-related basic knowledge is needed' could be interpreted as an introductory course), while more specified, closed-ended answers describe the respondent's expectations in more detailed way (e.g. 'upgrade of the EU-related basic knowledge is needed').

Secondly, according to the theory both the situations were training is needed to resolve the problem or deficiency as well situations where training in particular field is not a priority, should be identified. To prevent the misidentification of the training needs, in particular situations should be avoided where respondent would answer 'as expected' on the 'dangerous' questions. More precisely, should the respondents as well as the persons responsible for drawing up a survey assume that the sponsor of the survey would expect that the knowledge as well as the competencies of the respondent are at the highest possible level (so-called social desirability), the respondents could be afraid to admit that 
they need, for example, the EU-related basic training or sector-specific trainings. In the survey from 2008, the respondents provided following arguments on their motives when answers 'dangerous' questions (an extract from the interviews conducted): 'I can't discredit our ministry', 'all state officials are already experts in this field and should I admit that I would like to have training in particular field, I might be fired', 'should I as well as majority of my colleagues admit that we need training, it might have negative impact on our salaries as well as the perspectives to be promoted in the future'. This could be interpreted as a sign of the human fear which leads to the motivation to give answers 'as expected' and, here, public servants will be no exception. To avoid the 'expected answers', the target groups should be approached already before the beginning of the survey and the aims of the training needs identification process as well as confidentiality rules should be explained in advance. Also, to avoid misinterpretation in identification of the training needs, ambiguous or misleading scales (e.g. having 'very good', 'good' and 'satisfactory' as the only choices available; or using 'important' and 'quite important' besides other choices) should be avoided and clearly polarized scales should be used.

Additionally, on the basis of the identification process of the training needs conducted by the University of Tartu EuroCollege in 2008, a discrepancy between the results of the survey and the semi-structured interviews with high-ranking officials could be observed. The survey has identified the EU-related training needs in the following areas: how member states could influence the EU-partners (identified as an area where training is needed also in the survey conducted in 2002), the decision making process of the EU (identified as a need for training also in the survey conducted in 2013), and specifics of the EU member states. At the same time, in the semi-structured interviews with highranking officials (conducted after the surveys) the EU-related knowledge was considered as of secondary issue and shortcomings were mainly identified with regard to the introvert nature of the Estonian EU-related state officials, weak historical and societal background of the local EU-officialdom, and the lack of the courage/experience of expressing the opinions publicly. Considering the nature of the abovementioned shortcomings, it would be relatively complicated to address the problems by focusing only on the EU-related knowledge and using traditional training methods. Thus, to a certain degree even such a situation should be accepted where the organization's needs, objectives, and problems could not be addressed by conducting training.

Thirdly, since in all three surveys conducted in Estonia to determine the EU-related training needs of local EU-officialdom the respondents were asked to self-assess their current knowledge and training needs and/or the knowledge and training needs of the colleagues, based on academic literature one could hypothetically assume that a substantial part of the respondents - intentionally or unintentionally - tend to over- or underestimate their knowledge and, thus, inadequately estimate their training needs. At the same time, two of the surveys have not assessed the extent of the over- and underestimation of the knowledge and competencies (see Appendix 1). Thus, majority of studies have not included the controls enabling to test the Dunning-Kruger effect. Hereby, 
one could draw a conclusion that testing the actual competencies of the local EU-related officialdom has not been prioritized by the institutions ordering and settling the framework of the studies. For the institutions responsible for public administration training and development activities, the TNA based on the subjective self-assessment of the target group of training combined with the assessment of direct superior, subordinates and to the limited extent the assessment of the colleagues could constitute a comfortable solution which do not tackle the gap between the actual knowledge and the desirable competencies, but only between the actual knowledge and the subjectively estimated competencies. Thus, the approach is neither based on theoretical concepts stressing the importance of avoiding the Dunning-Kruger effect nor in practical terms enabling managing the risks of non-identification of actual training needs potentially occurring during the TNA process.

Thus, to get an adequate and comprehensive overview of the training needs, selfassessment should be combined with other instruments and techniques offering additional measurable information, as it have been done in the case of the survey conducted in 2008. An EU-related voluntary quiz was used to compare whether those who assess their knowledge as 'excellent' or 'very good' actually gain higher results in the test than those who mark their knowledge as 'medium' or 'weak'. The results of the quiz clearly indicate that respondents of the initial questionnaire tend to overestimate their basic EU-related knowledge, and that majority of the respondents assess their own knowledge and practical skills higher and training needs lower than of colleagues'. Thus, in areas where knowledge could be specified in a detailed way (e.g. the institutions and decision making process of the EU, or country positions in different policy areas), the authors of the current article would suggest to use quiz as a control to identify the training needs of the public servants. In principle, also other controls could be included, such as the knowledge and training needs of the respondent's colleagues could be discussed or the shortcomings and failures occurred in the daily work could be described during the interview, etc.

As a general comment, the authors of the article would like to note that in a situation where voluntary or anonymous controls (e.g. quiz) will be used, the response rate might be low as the respondents might prefer - due to the low motivation, lack of knowledge, or other factors - to skip the voluntary or anonymous controls. To avoid it, again intense cooperation with the respondents is of key importance, i.e. the respondents of the survey should be approached in an individual way as well as background information should be provided explaining the aim of the survey as well as the confidentiality rules.

\section{Conclusions}

The aim of the current study was to assess whether the human resource management instruments used in Estonian public sector have been appropriate in identifying the gap between the actual knowledge and desired competencies. The analysis was based on 
the comparison of TNA techniques applied in the studies conducted in Estonia respectively in 2002, 2008 and 2013 to determine the EU-related training needs of the local officialdom. Particular attention has been devoted to the scope of the needs' identification process, the occurrence of the answer 'as expected' on the 'dangerous' questions, and the subjective nature of self-assessment known as the Dunning-Kruger effect.

The authors of the current study agree with the statement made by Randma-Liiv et al. (2011) that in assessing the Estonian public administration training needs the TNA has been conducted in a non-systematic manner. At the same time, we would like to emphasize that the non-systematic assessment is not only related to the specific problems occurred at centrally co-ordinated level, organizational level as well as with regard to the training of top-ranked officials, but also related to the lack of consistent approach to the techniques used in TNA. For the institutions responsible for public administration training and development activities, the TNA based on the subjective selfassessment of the target group of training combined with the assessment of direct superior, subordinates and the colleagues presents a good example of institutional "negative" convenience where instead of searching for gaps between the actual knowledge and the desired competencies, the institutions are looking for further ways to show the existing competencies in a better light and excluding the tools reflecting the over- and underestimation of the knowledge and skills.

On the basis of the discussion above, authors of current study would suggest the following amendments into the current TNA methods used.

Firstly, the training needs' identification should rather take place in a detailed way focusing on assessing the current knowledge and the training needs in particular areas, not on the importance of the topics on a broad basis. Secondly, according to the argument above both the situations were training is needed to resolve a problem or deficiency as well situations where training in a particular field is not a priority, should be identified. Thirdly, based on the academic literature, unless a special attention is dedicated to avoid the problem, it is very likely that the respondents do not assess their training needs adequately - a socio-psychological phenomenon known as the DunningKruger effect -, which leads to a situation where neither the actual training needs of the local officialdom will be adequately ascertained, nor the well-targeted strategy to overcome the lack in actual knowledge will be produced. To get a comprehensive picture of the training needs, self-assessment should be combined with other instruments and techniques. Therefore, as perhaps the most easily applicable option, the authors of the current article suggest to include a knowledge quiz to the official part of the survey questionnaire in order to minimize the risks of over- and underestimation of the knowledge and skills.

To conclude in identifying the training needs, the process should be rather precisely focused on assessing the current knowledge and the training needs in particular areas, not on the qualitative and non-measurable competencies on a broad basis. Also, unless a 
longstanding, stable and widespread meaning pertains to non-numeric grades in a specific culture, numeric values of the assessment should be preferred instead of the criteria such as 'good', 'very good'. It would likewise be crucial to include a knowledgequiz to the official part of the survey questionnaire. Thus, the questionnaire should consist of two parts: a) the subjective self-assessment of the respondents' level of knowledge and, b) multiple-choice questions designed to match the topics under observation in the first part of the survey. On top of it, interviews with key officials would be indicative as well.

\section{References}

Avaliku teenistuse aastaraamat 2012 (2013), (Ministry of finance/Rahandusministeerium), available at: http://www.avalikteenistus.ee/public/statistika/ATAR 2012 v2.pdf (accessed 29. August 2014).

Barbazette, J. (2006), Training needs assessment: methods, tools, and techniques, Pfeiffer, San Francisco, Volume 1.

Cekada, T.L. (2011), "Need training? Conducting an Effective Needs Assessment", Professional Safety, ASSE (December 2011), Vol 56 (12), available at: http://www.asse.org/education/seminarfest13/docs/PSJ\%20Articles/Sem\%2052/Conducting\%20an\% 20effective\%20needs\%20assessment Cekada 1211Z.pdf (accessed 29. August 2014).

Cekada, T.L. (2010), "Training Needs Assessment: Understanding what employees need to know", Professional Safety, ASSE (March 2010), available at: http://www.asse.org/professionalsafety/docs/F1Cekada 0310.pdf (accessed 29. August 2014).

Coetzee, M. (2004), Empowering the Skills Development Facilitator, Knowres, Johannesburg.

Drechsler, W. (2004), "Enhancing the Capacities to Govern: Challenges Facing the CEE Countries", Selected Papers from the $11^{\text {th }}$ NISPAcee Annual Conference, refereed in Savi, R., and Metsma, M. (2013), Public Sector Reform in Estonia: Views and Experiences from Senior Executives. Country Report. Coordination for Cohesion in the Public Sector of the Future (COCOPS), available at: http://www.cocops.eu/wp-content/uploads/2013/06/Estonia WP3-Country-Report.pdf (accessed 29. August 2014).

Dunning, D., Johnson, K., Ehrlinger, J.E., and Kruger, J. (2003), "Why people fail to recognize their own competence", Current Directions in Psychological Science, June (12); pp. 83-87.

Gupta, K. (1999), A practical guide to needs assessment, Pfeiffer, San Francisco.

Hannum, W., and Hansen, C. (1989), Instructional systems development in large organizations, Englewood Cliffs, NJ: Educational Technologies Publications, referred in Cekada, T.L. (2010), "Training Needs Assessment: Understanding what employees need to know", Professional Safety, ASSE (March 2010), available at: http://www.asse.org/professionalsafety/docs/F1Cekada 0310.pdf (accessed 29 August 2014).

Kruger, J., and Dunning, D. (1999), “Unskilled and Unaware of It. How Difficulties in Recognizing One's Own Incompetence Lead to Inflated Self-Assessments", Journal of Personality and Social Psychology, Vol 77, No 6, pp. 1121-1134, available at: http://www.jerwoodno.org.uk/pdf/Dunning\%20Kruger.pdf (accessed 29 August 2014). 
Lind, D.S., Rekkas, S., Bui, V., Lam, T., Beierle, E. and Copeland, E.M. (2002), "Competency-based student self-assessment on a surgery rotation", Journal of Surgical Research, Vol 105 (1), pp. 31-34.

McCawley, P. (2009), Methods for Conducting an Educational Needs Assessment, University of Idaho Extension, available at: http://www.cals.uidaho.edu/edcomm/pdf/bul/bul0870.pdf (accessed 29 August 2014).

McClelland, S.B. (1994), "Training Needs Assessment Data-gathering Methods: Part 3, Focus Groups", Journal of European Industrial Training, Vol 18 (3), pp. 29-32.

McGehee, W., and Thayer, P. (1961), Training in business and industry, Wiley, New York.

Miller, J.A, and Osinki, D.M. (2002), Training needs assessment, International Society for Performance Improvement, available at: www.ispi.org/pdf/suggestedReading/Miller Osinski.pdf (accessed 29 August 2014).

Moore, M., and Dutton, P. (1978), "Training Needs Analysis: Review and Critique", The Academy of Management Review, Vol. 3. No. 3 (July), pp. 532-545.

Moseley, J.L., and Heaney, M.J. (1994), "Needs assessment across disciplines", Performance Improvement Quarterly, No 7, pp. 60-79.

OECD (1997), "Public Service Training in OECD Countries", SIGMA Papers, No 16. OECD Publishing, available at: http://www.oecdilibrary.org/docserver/download/5kml619ljzzn.pdf?expires=1401553266\&id=id\&accname=guest\&che cksum=B69570B2502F96D97E89465B783E9BFC (accessed 29. August 2014).

Pallier, G. (2003), "Gender differences in the self-assessment of accuracy on cognitive tasks", Sex Roles: $A$ Journal of Research, Vol 48, Issue 5-6 (March), pp. 265-276, available at: http://business.highbeam.com/435388/article-1G1-100630998/gender-differences-selfassessmentaccuracy-cognitive (accessed 29 August 2014).

Patton, W.D., and Pratt, C. (2002), "Assessing the training needs of high-potential managers", Public Personnel Management, Vol. 31 No. 4, pp. 465-84.

Pazicni, S. and Bauer, C.F. (2014), "Characterizing illusion of competence in introductory chemistry students", Chemistry Education Research and Practice, Vol 15, pp. 24-34.

PRAXIS (2013), EL otsustusprotsessiga seotud ametnike ja poliitikute koolitusvajaduse hindamine Euroopa Liidu nõukogu eesistumise läbiviimiseks vajalike kompetentside arendamiseks, compiled by Uudelepp, A., Altermann, A., Anton, A., Järvalt, J., Matt, J., and Vinni, R., PRAXIS, available at: http://www.praxis.ee/fileadmin/tarmo/Projektid/Valitsemine ja kodanike\%C3\%BChiskond/EL eesistu mise koolitusvajaduse uuringu raport.pdf (accessed 29. August 2014).

Randma-Liiv, T. (2009), Avaliku teenistuse seaduse eelnõu (538SE): ekspertarvamus, published in 28 October 2009, available at: http://www.riigikogu.ee/doc.php?55263 (accessed 29 August 2014).

Randma-Liiv, T., Sarapuu, K., Uudelepp, A., Metsma, M. (2011), Avaliku teenistuse koolitussüsteemi ja arenguvajaduste analüüs, SA Poliitikauuringute Keskus PRAXIS and Tallinna Tehnikaülikooli Avaliku Halduse Instituut, available at: http://www.praxis.ee/fileadmin/tarmo/Projektid/Valitsemine ja kodanike\%C3\%BChiskond/ATKOS lo ppraport 2011.pdf (accessed 29 August 2014).

Sarapuu, K. (2012), "Administrative Structure in Times of Changes", International Journal of Public Administration, Vol. 35, Issue 12, pp. 808-819. 
Sepp, V., and Noorkõiv, R. (2006), Kohalike omavalitsuse üksuste ametnike pikaajalise koolitusvajaduse uuring, Geomedia OÜ.

Sorenson, S.M. (2002), "Training for the long run", Engineered Systems, Vol. 19, No 6, available at: http://www.sukimcintosh.com/articles/TrainingfortheLongRun.pdf (accessed 29 August 2014).

Taavits, G. (2012), „Avaliku teenistuse õigusliku reguleerimise probleemid“, presentation available at: http://www.google.ee/url?sa=t\&rct=j\&q=\&esrc=s\&source=web\&cd=1\&ved=0CCwQFjAA\&url=http\%3 A\%2F\%2Fwww.sisekaitse.ee\%2Fpublic\%2FGaabriel Tavits.ppt\&ei=qvqJU4eFL4PA7Abn94HgCg\&u sg=AFQjCNGoOMv9XrvKIGW2wHFFhKDkrvi7cA ((accessed 29 August 2014).

Tõnnisson, K., and Randma-Liiv, T. (2008), "Public Management Reforms: Estonia", in Bouckaert, G., Nemec, J., Nakrosis, V., Hajnal, G., and Tõnnisson, K. (Eds.) (2008), Public Management Reforms in Central and Eastern Europe. Bratislava: NISPA (Network of Institutes and Schools of Public Administration in Central Eastern Europe), pp. 93-118. Refereed in Savi, R., and Metsma, M., (2013), Public Sector Reform in Estonia: Views and Experiences from Senior Executives. Country Report. Coordination for Cohesion in the Public Sector of the Future (COCOPS), available at: http://www.cocops.eu/wp-content/uploads/2013/06/Estonia WP3-Country-Report.pdf (accessed 29. August 2014).

University of Tartu EuroCollege (2008), Euroopa Liidu otsustusprotsessis osalevate ametnike Euroopa Liidu alase täienduskoolituse vajaduse uuring 2008-2013, compiled by Ehin, P., Veebel, V., Rämmer, A, Hurt, U., Luht, L., Luik, T., Urb, J., Uus, K., and Veski, L., University of Tartu EuroCollege, Tartu, available

at: http://www.avalikteenistus.ee/public/Uuringu anal si tervikraport 24 aprill.pdf (accessed 29 August 2014).

Waxin, M.-F., and Bateman, R. (2009), "HRM in the public sector: is it enough", Chapter 3 in International Handbook of Public Management Reform, Goldfinch, S.F., and Wallis, J.L. (Eds.), Edward Elgar Publishing. 